\title{
IMPACTS OF MARINE RANCHING CONSTRUCTION ON SEDIMENT PORE WATER CHARACTERISTIC AND NUTRIENT FLUX ACROSS THE SEDIMENT-WATER INTERFACE IN A SUBTROPICAL MARINE RANCHING (ZHELIN BAY, CHINA)
}

\author{
QIN, C. ${ }^{1,2,3^{*}}-$ CHEN, P. ${ }^{1,2,3}-$ ZHANG, A. ${ }^{1}-$ FENG, X. ${ }^{1,2,3}-$ YUAN, H. ${ }^{1,2,3}-$ LI, X. ${ }^{1,2,3}-$ YU, J. ${ }^{1,2}-$ \\ LEBER, K. M. \\ ${ }^{1}$ South China Sea Fisheries Research Institute, Chinese Academy of Fishery Sciences \\ 510300 Guangzhou, China
}

${ }^{2}$ Scientific Observing and Experimental Station of South China Sea Fishery Stock and Environment, Ministry of Agriculture 510300 Guangzhou, China

${ }^{3}$ Key Laboratory of Marine Ranching, Chinese Academy of Fishery Sciences 510300 Guangzhou, China

${ }^{4}$ Mote Marine Laboratory Sarasota, FL 34236, USA

*Corresponding author e-mail: qincx@scsfri.ac.cn; phone: +86-20-8910-3365; fax: +86-20-8910-3365

(Received 22 ${ }^{\text {nd }}$ Aug 2017; accepted $8^{\text {th }}$ Nov 2017)

\begin{abstract}
Marine ranching is an effective way to restore depleted stocks and increase fisheries production. The effects of marine ranching construction on sediment pore water characteristics and nutrient flux across the sediment-water interface were determined by incubation experiments. Nine stations were selected along an inshore to offshore gradient of different sediment types representing different zones used for marine ranching in Zhelin Bay, China. The results showed that nutrient concentrations of overlying water and pore water varied by zone and were influenced by biological and physical characteristics. In the macroalgae zone (MA), macroalgae was cultured from September to May Decayed macroalgae in this zone during winter lead to $\mathrm{pH}$ variation (ranged from 8.05 to 8.16) and highest nitrite (range from 0.1719 to $0.9210 \mathrm{umol} \mathrm{m}^{-2} \mathrm{D}^{-1}$ ), ammonia (range from 1.778 to $4.448 \mathrm{umol} \mathrm{m}^{-2}$ $\mathrm{D}^{-1}$ ) and total nitrogen (range from 23.43 to $140.6 \mathrm{umol} \mathrm{m}^{-2} \mathrm{D}^{-1}$ ). In the benthic molluscs' area, shellfish activities led to higher ammonia (range from 0.3312 to $7.725 \mathrm{umol} \mathrm{L}^{-1}$ ) and total nitrogen (range from 59.67 to 447.7 umol L ${ }^{-1}$ ) concentration in the overlying water during the summer season. In the artificial reef zone (depth 15-20 m), the deployment of artificial reef materials altered the sea floor which resulted in upwelling and a consequent increase in the flux of total phosphate. The results of this study will be useful to improve marine ranching efforts in China and worldwide.
\end{abstract}

Keywords: fishery, macroalgae, benthic molluscs, artificial reef, water quality

\section{Introduction}

Sustainable fisheries are a useful way to restore depleted stocks and increase production (Bell et al., 2008; Taylor et al., 2016). Stock enhancement and marine ranching have been proven to be an effective method to increase stocks (Camp et al., 2013; Hair et al., 2016; Leber et al., 2004; Lorenzen et al., 2010; Han et al., 2016). In recent years, marine ranching combined with artificial reef deployment has been used on a massive scale in China, Japan and other countries (Leber et al., 2004). A typical marine ranch in China is divided into four functional components including the artificial 
reef zone, macroalgae zone, mollusc zone and floating reef zone (Chen et al., 2015) and each zone has different ecological function. The artificial reef zone and floating reef zone provide shelter for fishery resources and enhance water nutrient; shellfish in the mollusc zone feed on microalgae; macroalgae absorb nutrients decrease red tide and provide food for human consumption.

The impacts of marine ranching on the physical, chemical and biological environments in each functional part would be significantly different (GaertnerMazouni et al., 2012; Layman et al., 2016; Raoux et al., 2017; Seaman, 2000; Wang et al., 2016; Wu et al., 2016). Thus, it is important to evaluate the biogeochemical changes associated with marine ranching construction. Models of mass fluxes and transformations of nutrients were used to describe the physical and biogeochemical process (Arndt et al., 2009; Denis and Grenz, 2003; Hu and Li, 2009; Miller, 1984; Rasheed et al., 2003). Dominant macrofauna enhanced benthic molecular diffusion and changed the biochemical processes in sediment (Zheng, 2011). Warnken et al. (2003) found shrimp trawling with removal of the upper oxic sediment layers could trend in benthic-pelagic coupling. Layman et al. (2016) proved that artificial reef deployment would enhance the primary production in seagrass ecosystem. Yet this rather general observation leaves many things unexplained about specific mechanistic links between marine ranching construction and nutrient supply.

The aim of this study was to assess nutrient fluxes across sediment-water interface and to evaluate the effects of marine ranching construction - artificial reef deployment, mollusc enhancement and macroalgae culture on sediment biogeochemistry. To help constrain the results, we have chosen a study site where benthic animal and fishery resources have been surveyed previously (Chen et al., 2015).

\section{Materials and methods}

\section{Study area and sampling}

Zhelin Bay is located in the north of Guangdong Province, China, with an area of $1320 \mathrm{~km}^{2}$. It was an important fishing ground of the north South China Sea. However, increased fishing effort in this area has led to a substantial decline in its fishery resources. Thus, to enhance fishery resources the area was selected as a location for constructing a Zhelin marine ranching system (ZSR). There are four parts in ZSR; the artificial reef zone (AR), the benthic molluscs zone (BM), the macroalgea zone (MA) and the floating reef zone (cages) (FR). Sampling sites in ZSR were selected in AR, BM and MA respectively.

Sediment cores were collected at the selected sites by SCUBA in two seasons (summer and winter) in 2012 (Table 1, Figure 1).

Table 1. Location of sample sites

\begin{tabular}{c|c|c|c}
\hline Stations & Description & Latitude (North) & Longtitude (East) \\
\hline S & & $117^{\circ} 00^{\prime} 10.80^{\prime \prime}$ & $23^{\circ} 32^{\prime} 27.60^{\prime \prime}$ \\
S & Macroalgae cultured area & $117^{\circ} 03^{\prime} 32.40^{\prime \prime}$ & $23^{\circ} 32^{\prime} 27.60^{\prime \prime}$ \\
S & & $117^{\circ} 06^{\prime} 05.40^{\prime \prime}$ & $23^{\circ} 30^{\prime} 00.00^{\prime \prime}$ \\
AR & & $117^{\circ} 10^{\prime} 15.60^{\prime \prime}$ & $23^{\circ} 31^{\prime} 01.20^{\prime \prime}$ \\
AR & Artificial reef deployed area & $117^{\circ} 10^{\prime} 15.60^{\prime \prime}$ & $23^{\circ} 29^{\prime} 34.80^{\prime \prime}$ \\
AR & & $117^{\circ} 11^{\prime \prime} 24.00^{\prime \prime}$ & $23^{\circ} 29^{\prime} 34.80^{\prime \prime}$ \\
M & & $117^{\circ} 05^{\prime} 60.00^{\prime \prime}$ & $23^{\circ} 28^{\prime} 13.80^{\prime \prime}$ \\
M & Molluscs enhanced area & $117^{\circ} 03^{\prime} 21.00^{\prime \prime}$ & $23^{\circ} 28^{\prime} 46.80^{\prime \prime}$ \\
M & & $117^{\circ} 01^{\prime} 17.88^{\prime \prime}$ & $23^{\circ} 26^{\prime} 56.40^{\prime \prime}$ \\
\hline
\end{tabular}




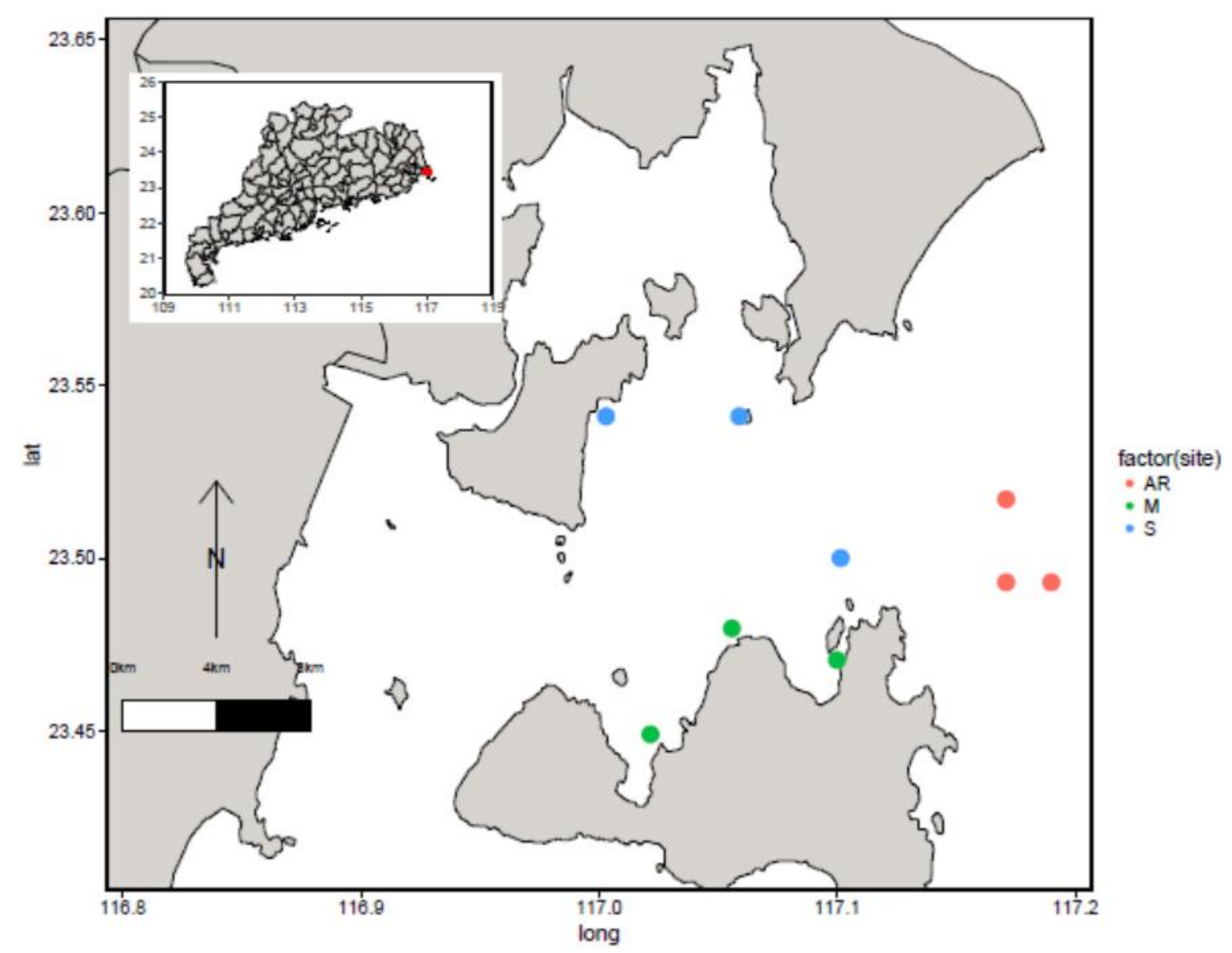

Figure 1. Sample sites in Zhelin Bay marine ranching, China. AR: artificial reef deployed area; M: molluscs enhanced area; $S$ : macroalgae cultured area

Sediment cores of 0-30 cm were collected with stainless steel column sampler $(5 \mathrm{~cm}$ in diameter). Then, sediment cores were transferred into transparent PVC wetland column without disturbance $(30 \mathrm{~cm}$ in height and $5 \mathrm{~cm}$ in diameter), and immediately frozen $\left(-20{ }^{\circ} \mathrm{C}\right)$ and preserved with $\mathrm{HgCl}_{2}$ until analysis was performed.

\section{Nutrient incubated fluxes}

The incubation device used in this study was designed by Qin et al. (2012) (Fig. 2). Samples were collected as $15 \mathrm{~cm}$-long sediment cores including $15 \mathrm{~cm}$ of the overlying water column. Each sediment core was sliced at $2 \mathrm{~cm}$ intervals over the first $10 \mathrm{~cm}$ with Rhizon to collect pore water (Seeberg-Elverfeldt et al., 2005) (Fig. 3). The temperature of the dark refrigerated cabinets was set at $10{ }^{\circ} \mathrm{C}$ and $25{ }^{\circ} \mathrm{C}$ to simulate the winter and summer temperature of ZSR, respectively. The overlying water was centrifuged at 50 $\mathrm{r} / \mathrm{min}$ at AR samples, $40 \mathrm{r} / \mathrm{min}$ at $\mathrm{BM}$ samples, $30 \mathrm{r} / \mathrm{min}$ at MA with a motor rotating propeller which was positioned at the same distance $(10 \mathrm{~cm})$ above the sediment surface in all core tubes. The differences of revs among samples of different areas are according to the water current of the areas. All sea water samples were taken from ZSR before each experiment and returned to the lab with $4{ }^{\circ} \mathrm{C}$ cabinet. Sampling of the overlying water was done by a plastic outlet at $0 \mathrm{~h}, 4 \mathrm{~h}, 8 \mathrm{~h}, 12 \mathrm{~h}, 24 \mathrm{~h}, 36 \mathrm{~h}$, and $48 \mathrm{~h}$ and pore water by means of Rhizon at $8 \mathrm{~h}$ and $48 \mathrm{~h}$ of the incubation period. The water volume removed during sampling was compensated by simultaneous input through the inlet, which retained the physical and chemical properties and total volume in the overlying water. 


$$
-166-
$$

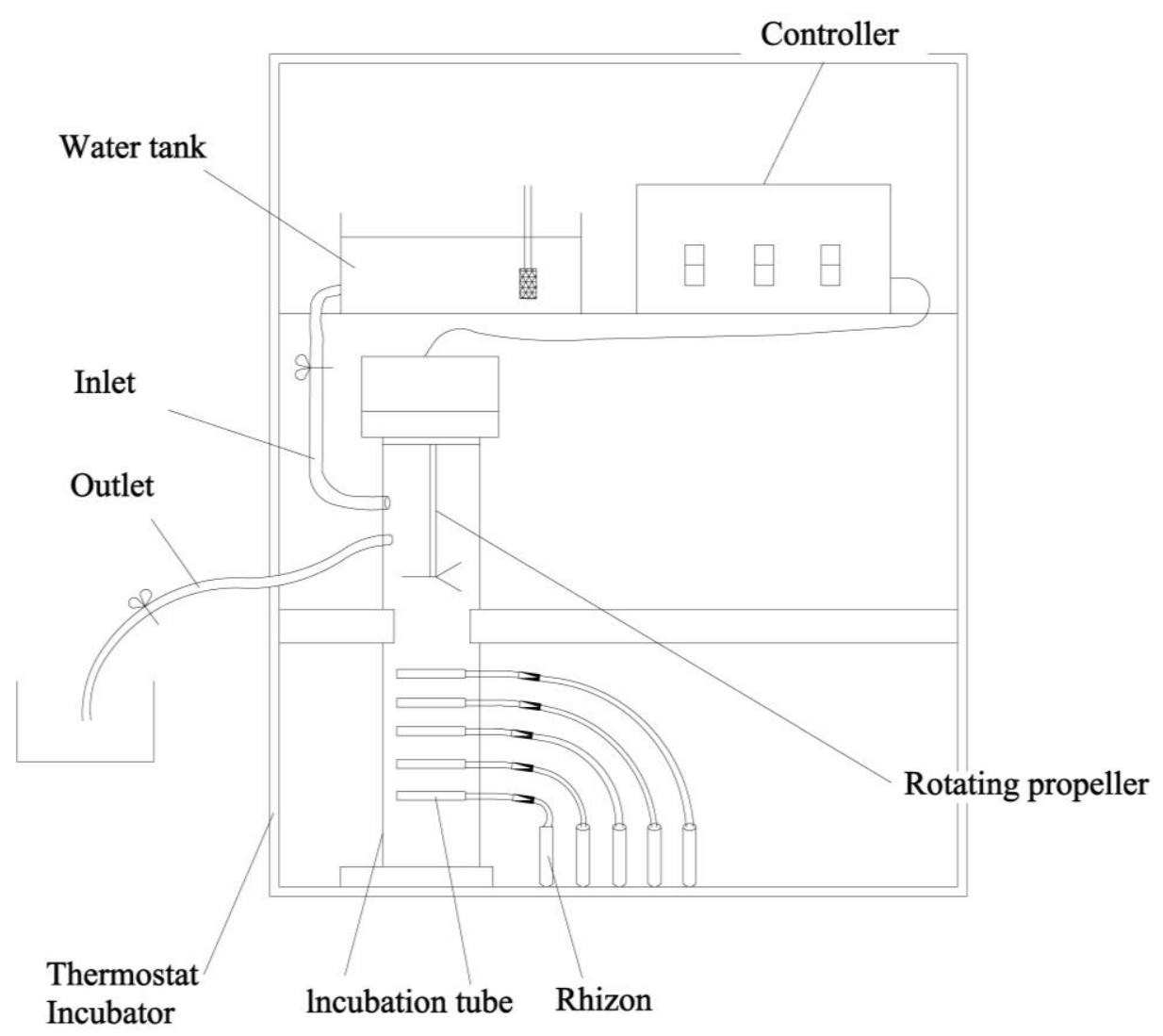

Figure 2. Equipment used for measurements of benthic nutrient fluxes during incubations

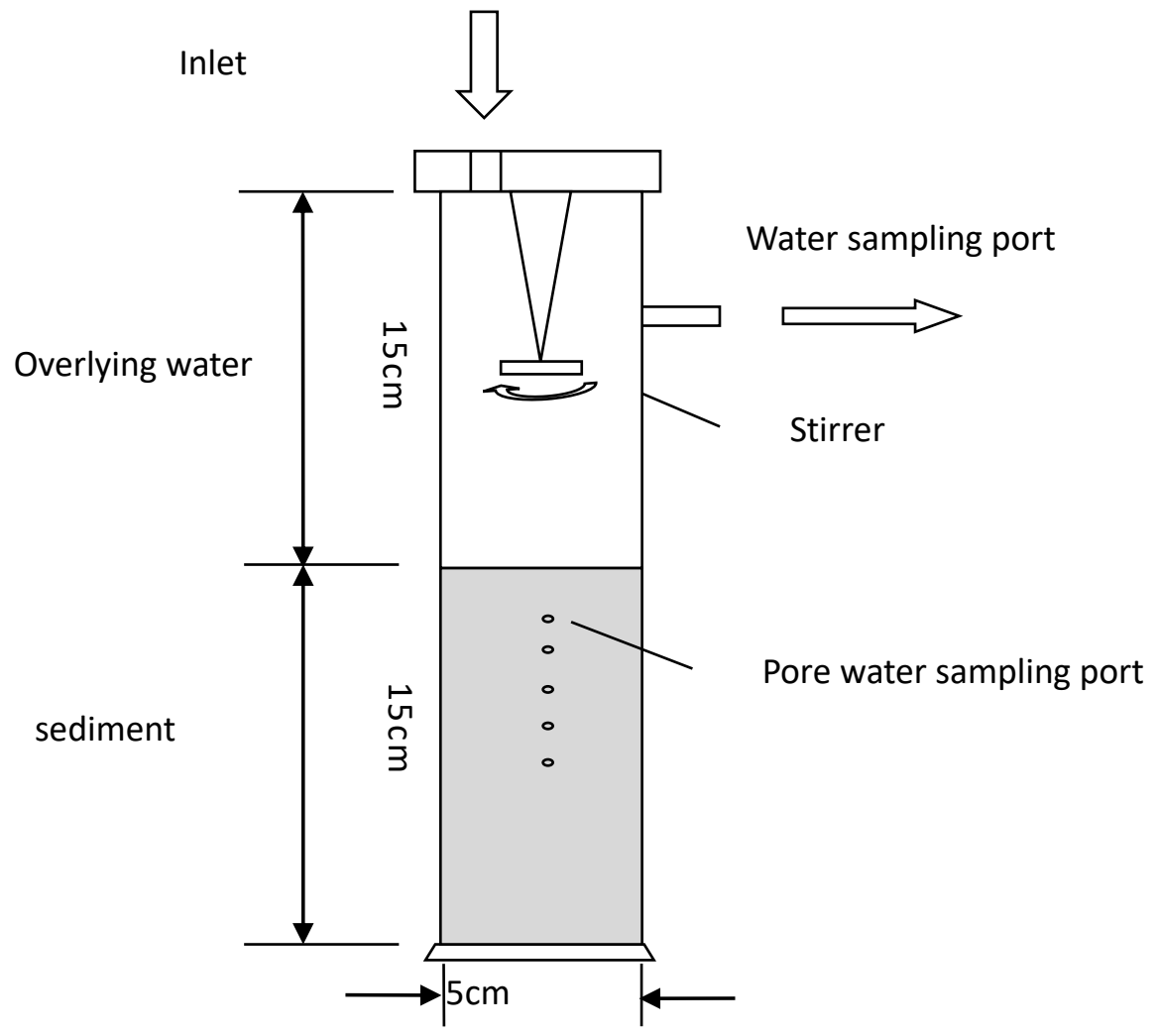

Figure 3. The incubation tube of incubation device

APPLIED ECOLOGY AND ENVIRONMENTAL RESEARCH 16(1):163-179.

http://www.aloki.hu • ISSN 15891623 (Print) • ISSN 17850037 (Online)

DOI: http://dx.doi.org/10.15666/aeer/1601_163179

(C) 2018, ALÖKI Kft., Budapest, Hungary 
DO and $\mathrm{pH}$ of overlying water were analyzed using a hand held YSI (YSI 650, YSI Incorporated). The overlying water and pore water samples were rapidly filtered using Whatman filter paper (Pore $0.45 \mathrm{um}$ and diameter $47 \mathrm{~mm}$; Whatman Inc., Florham Park, $\mathrm{NJ})$ and analyzed for ammonia $\left(\mathrm{NH}_{4}{ }^{+}\right)$, nitrite $\left(\mathrm{NO}_{2}{ }^{-}\right)$, phosphate $\left(\mathrm{PO}_{4}{ }^{3-}\right)$, total nitrogen (TN) and total phosphorus (TP). Concentration of $\mathrm{NH}_{4}{ }^{+}, \mathrm{NO}_{2}{ }^{-}, \mathrm{PO}_{4}{ }^{3-}, \mathrm{TN}$ and $\mathrm{TP}$ were determined spectrophotometerically using FIAstar5000 nutrient analyzer (FOSS Company) according to the methods described by Grasshoff et al. (2009).

\section{Fluxes calculation and data analysis}

The fluxes of $\mathrm{NH}_{4}{ }^{+}, \mathrm{NO}_{2}{ }^{-}, \mathrm{PO}_{4}{ }^{3-}, \mathrm{TN}$ and $\mathrm{TP}$ across sediment-water interface were calculated according to Fick's $1^{\text {st }}$ law and using the following formula (Eq. 1) (Sakamaki et al., 2006):

$$
F=\frac{\left[\left(c_{s}-c_{i}\right)-\left(c_{s}^{t}-c_{i}^{J}\right)\right]}{\left(t_{i}-t_{j}\right) \times A} \times V
$$

where $F$ is the nutrient flux $\left(\mathrm{mg} \mathrm{m}^{-2} \mathrm{~h}^{-1}\right), C_{\sigma}$ and $C_{i}$ are the nutrient concentration in the overlying water and pore water at the time of $t_{j}, C_{s}^{\prime}$ and $C_{i}^{\prime}$ are the nutrient concentration in the overlying water and pore water at the time of $t_{i}, t_{j}$ and $t_{i}$ is the time of beginning of incubation and end of incubation, individually, $\mathrm{A}$ is the sediment surface area in incubation tube and $\mathrm{V}$ is water volume.

Fluxes between the different pore water were calculated as follows (Eq. 2) (Zhang et al., 2013):

$$
F=\frac{\left(c_{s}-c_{i}\right)}{\left(t_{i}-t_{j}\right)} \times H
$$

where $H$ was the height between the different pore.

A series of possible fits are compared through statistical $F$ testing. Fluxes were calculated as slopes of linear regression of the changes in nutrient concentrations against time. Statistical significance of regression analysis was evaluated by a criterion of $p<0.05$.

\section{Results}

\section{Overlying water}

DO and $\mathrm{pH}$ in the overlying water are illustrated in Figure 4. Dissolved oxygen in the overlying water decreased quickly in the first $4 \mathrm{~h}$ and then remained at a relatively stable concentration; no obvious differences were found among sites and seasons. The exception was site AR and MA in summer, where lower DO values were measured. Higher depleted rate of DO concentrations in site MA were probably due to decaying macroalgae (Wang et al., 2016). Otherwise, artificial reef construction will affect the local physical dynamics in the small-scale environments (Kim et al., 2016; Seaman, 2000). A large reef structure can create locally significant vertical upwelled current and cause resuspension or scouring of sediment around the reef bottom.

The concentration of $\mathrm{NH}_{4}{ }^{+}, \mathrm{NO}_{2}{ }^{-}$and $\mathrm{PO}_{4}{ }^{3-}$ was highly variable (Fig. 5). Ammonium is higher than nitrite in site $\mathrm{BM}$ and MA during the incubated period. The highest 
concentration of ammonium was found in summer at site BM $\left(11.99 \pm 2.01 \mathrm{umol} \mathrm{L}^{-1}\right.$, after $24 \mathrm{~h}$ incubation in summer). At site AR the concentration of ammonium in summer is lower than during winter. However, the trend of nitrite is reversed. At site BM, Nitrite levels are the lowest among all sites, though ammonium level was the highest. Phosphate concentrations were low at sites BM and MA (Fig. 6). Phosphate concentrations revealed no obvious differences among all sites and seasons (summer and winter, $P>0.05$ ). Highest phosphate levels were found in winter after a $4 \mathrm{~h}$ incubation period at site AR $\left(5.360 \mathrm{umol} \mathrm{L} \mathrm{L}^{-1}\right)$.
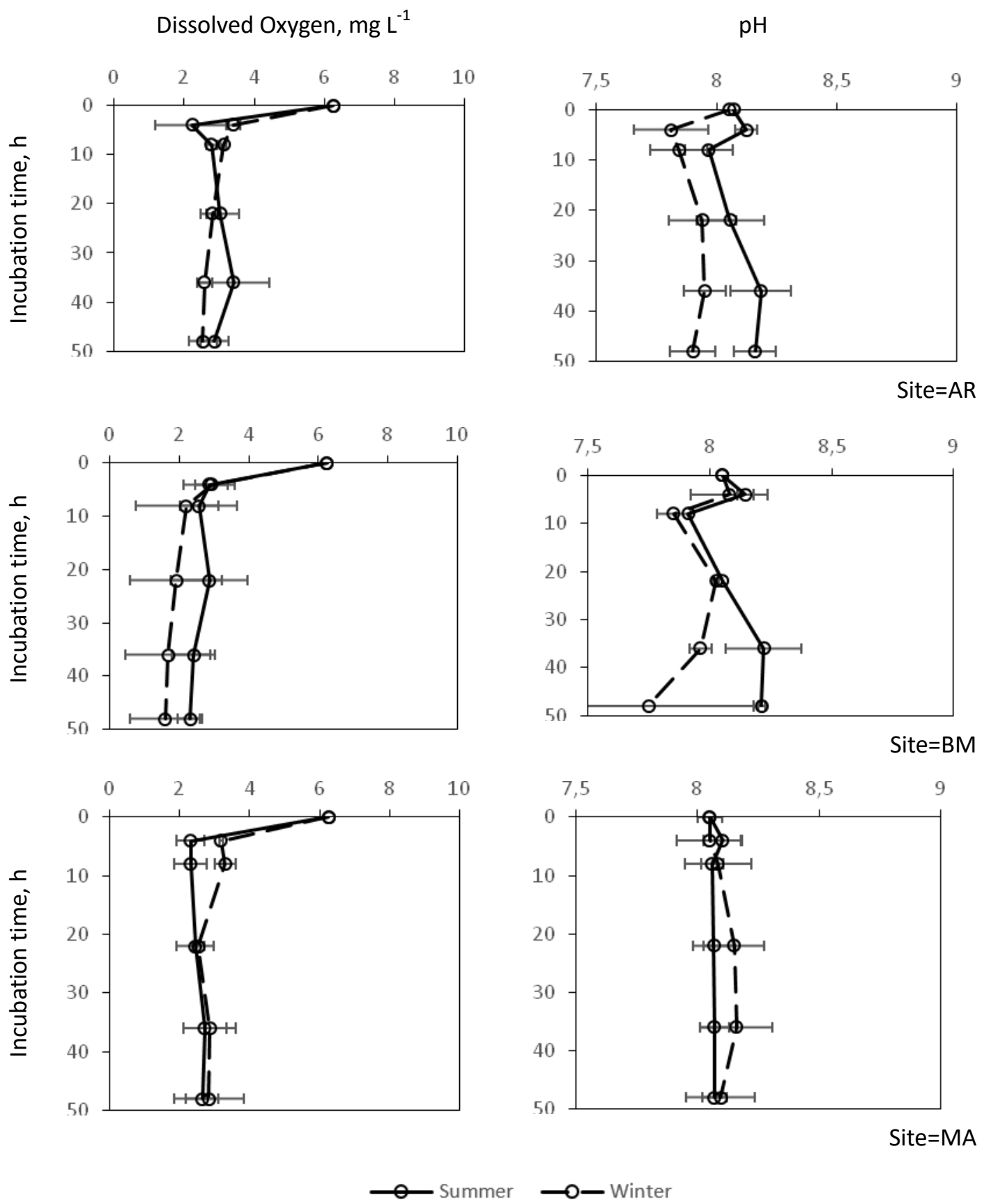

Figure 4. Time course of $\mathrm{DO}$ and $\mathrm{pH}$ in the overlying water during the incubation in summer and winter 


$$
-169-
$$

$\mathrm{NH}_{4}^{+}$, umol L ${ }^{-1}$
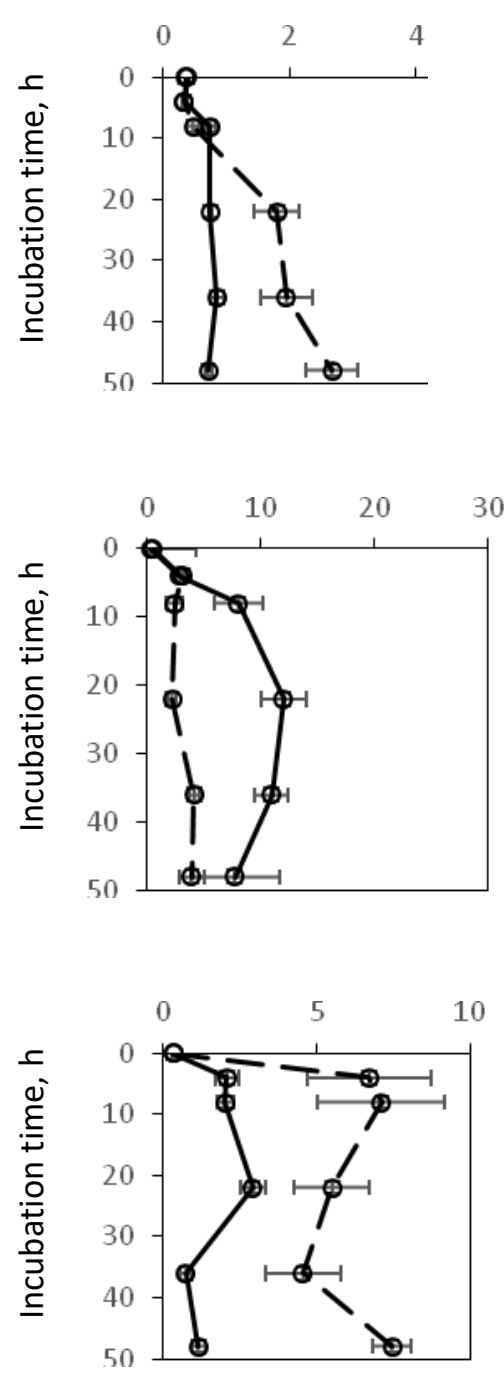

$\mathrm{NO}_{2}^{-}$, umol L $^{-1}$
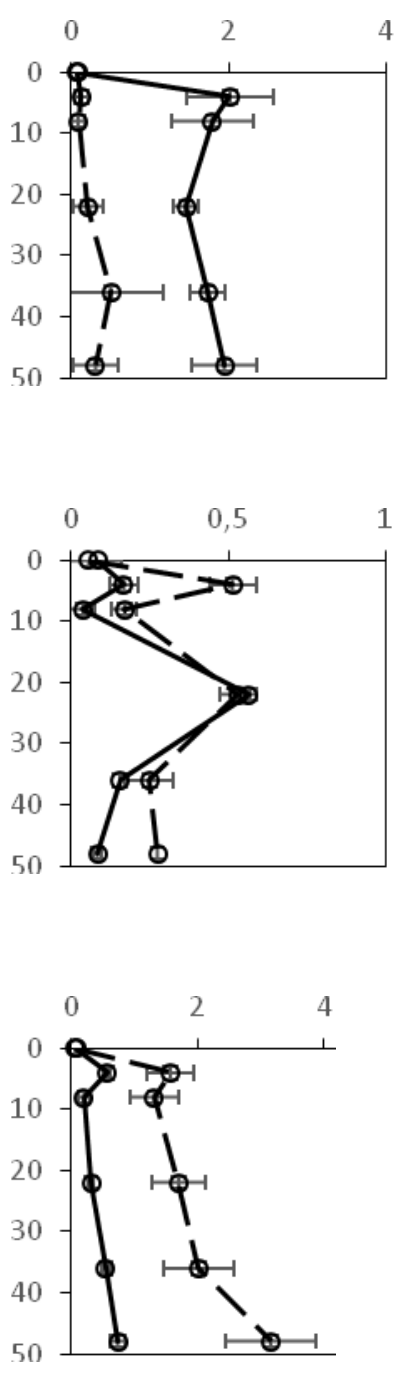

- Summer $\longrightarrow$-Winter
$\mathrm{PO}_{4}^{3-}$, umol L$^{-1}$
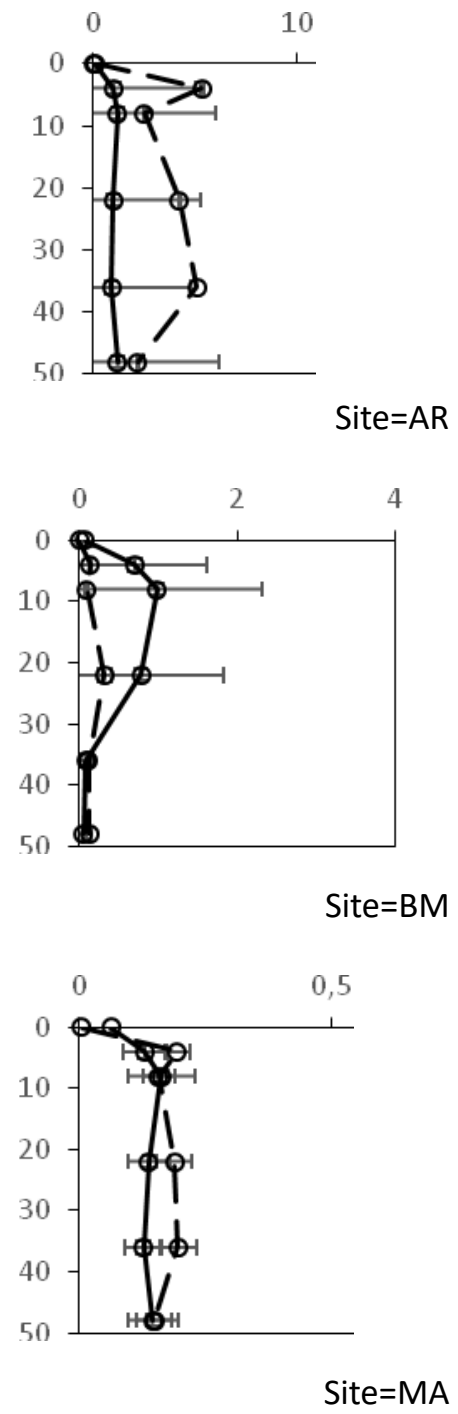

Figure 5. Time course of ammonium, nitrite and phosphate during the incubation in spring and winter

The range of $\mathrm{TN}$ and $\mathrm{TP}$ concentration in the overlying water throughout the incubation time was about one order of magnitude greater than TN and TP variations observed during the first 4-h incubations (Fig. 5). The TN levels were always higher than TP in both seasons and at all sites. The highest TN concentrations $(447.1 \pm 63.32$ umol $\mathrm{L}^{-1}$ ) were found in summer at site BM. After incubation the higher TN concentration were found at site AR in winter $\left(325.8 \pm 46.83 \mathrm{umol} \mathrm{L}^{-1}\right)$ and at site MA in both summer and winter $\left(328.5 \pm 30.61 \mathrm{umol} \mathrm{L}^{-1}\right.$ and $330.3 \pm 50.97$ umol L $\mathrm{L}^{-1}$, respectively). TP concentrations were generally lower in summer and winter at site AR and in winter at site MA. These results mean that the high density of mollusc in site BM had bioturbation effects on benthic biogeochemistry. 
$\mathrm{TN}$, umol L $\mathrm{L}^{-1}$
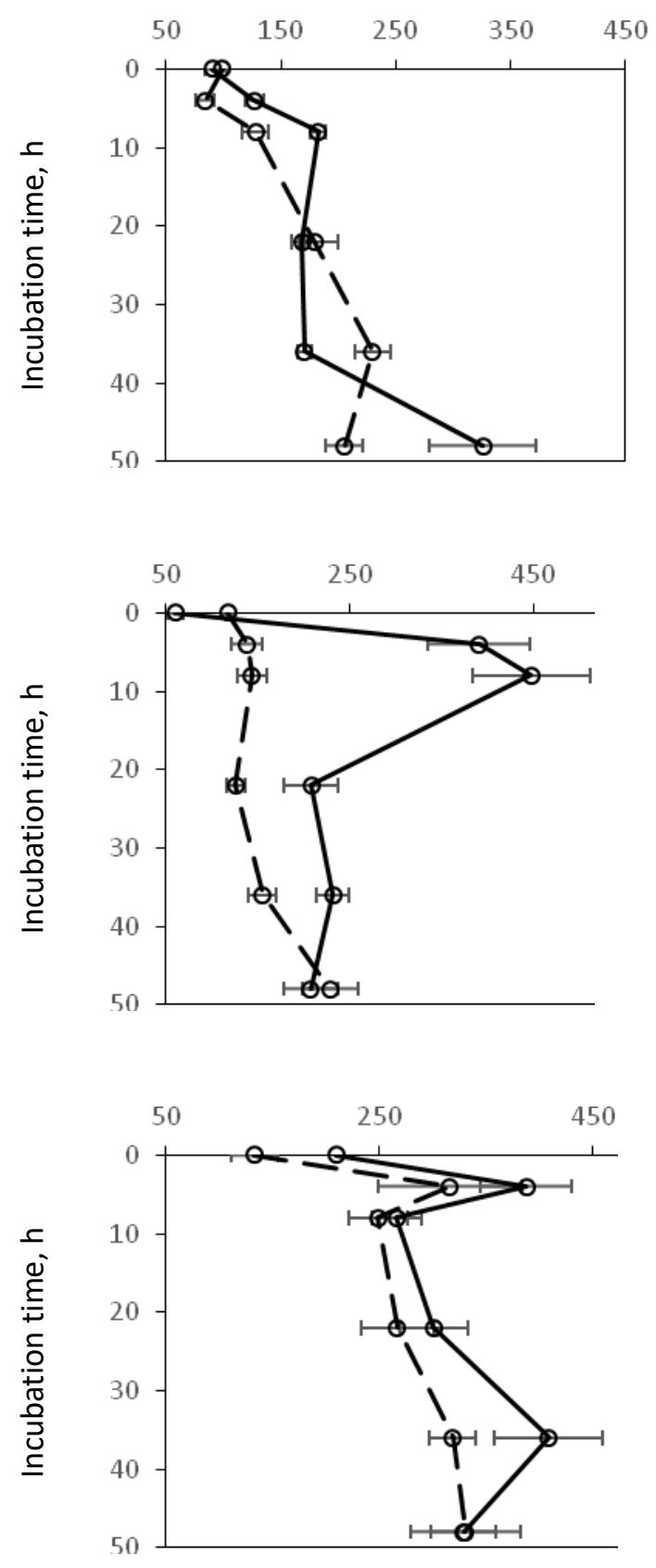

TP, umol L $\mathrm{L}^{-1}$

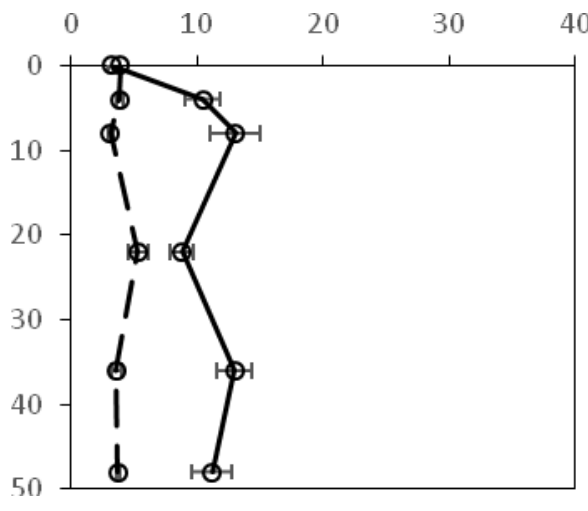

Site $=A R$
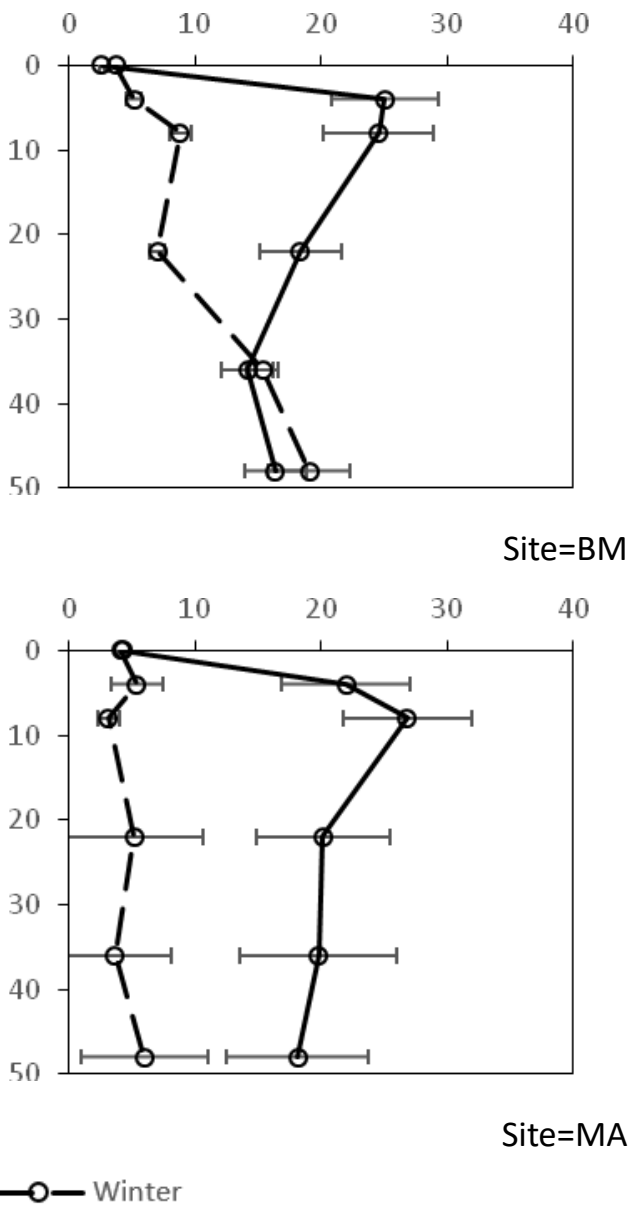

Figure 6. TN and TP in the overlying water in summer and winter

\section{Pore water}

For all sites, ammonium, nitrite and phosphate concentrations showed a sharp increase in the first $2 \mathrm{~cm}$ depth of the sediment and then demonstrated regular fluctuations with depth (Fig. 7). The pore water ammonium concentrations were approximately similar at both sites BM and MA for both seasons (varying from 2.428 to 
55.68 umol L $\mathrm{L}^{-1}$ and from 1.996 to $54.03 \mathrm{umol} \mathrm{L}^{-1}$ in sites BM and MA respectively). The highest ammonium concentrations were detected at site AR in winter $(77.50$ umol L-1). Nitrite concentration showed a similar trend to ammonium, however the highest nitrite concentration 1182.14 umol L ${ }^{-1}$ was found at site MA in summer after $48 \mathrm{~h}$ of incubation. The pore water phosphate ${ }^{-}$concentration showed a gradual increase with depth and no conspicuous difference between the two seasons. However, phosphate concentration at site AR showed higher value than the other sites and with a strong positive gradient in overlying water. Significant variation $(p<0.05)$ of nitrite concentration with seasons were detected only in sites AR and BM. There are no significant differences between $8 \mathrm{~h}$ incubation and $48 \mathrm{~h}$ of incubation for ammonium, nitrite and phosphate concentrations $(p>0.05)$. TP and TN showed almost similar trend (Fig. 8). Total phosphate concentration at site BM was significantly lower than at site AR and MA (varying from 3.092 to $116.7 \mathrm{umol} \mathrm{L}^{-1}$, from 8.802 to $167.00 \mathrm{umol} \mathrm{L}^{-1}$ and from 3.112 to $187.2 \mathrm{umol} \mathrm{L}^{-1}$ in site $\mathrm{BM}$, AR and MA respectively).
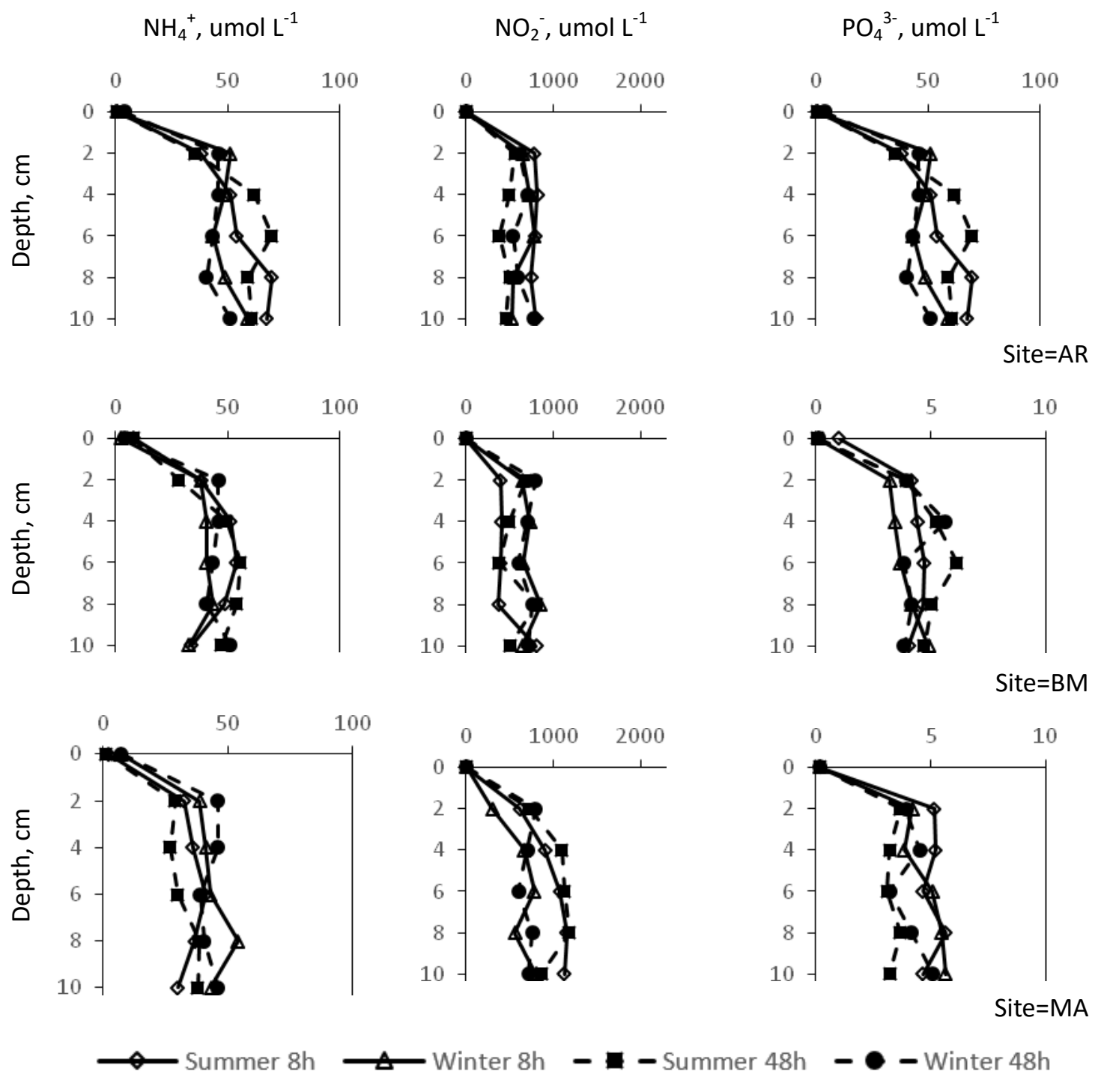

Winter $8 \mathrm{~h}$
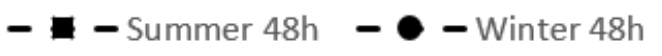

Figure 7. Ammonium, nitrite and phosphate in the pore water after 8 and 48 h of incubation for spring and winter 

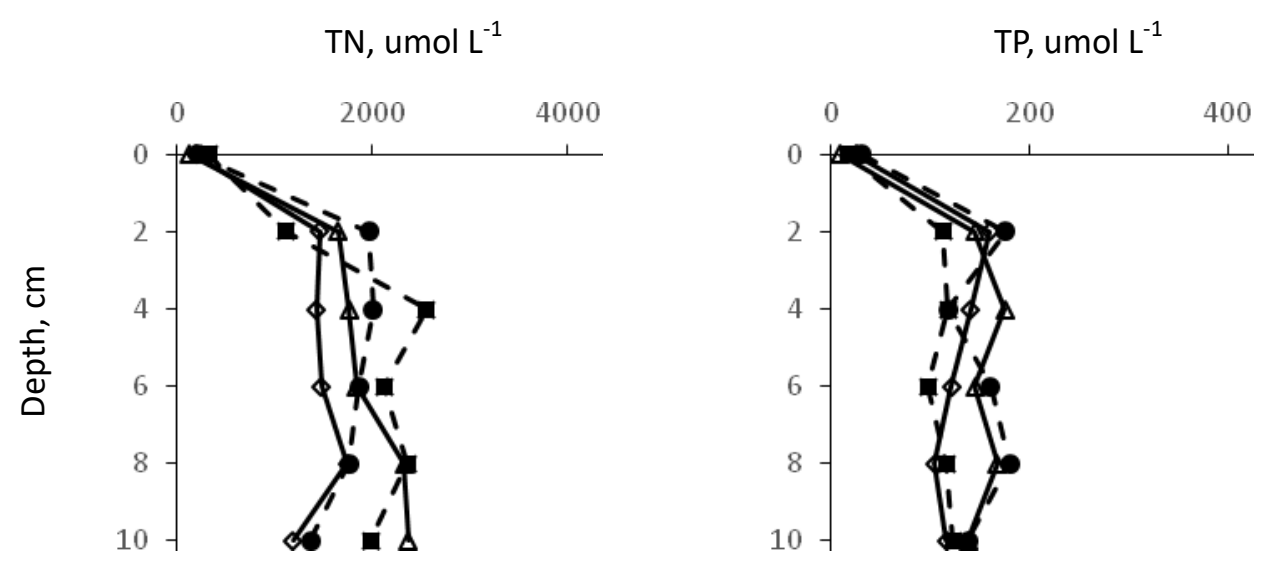

Site $=A R$
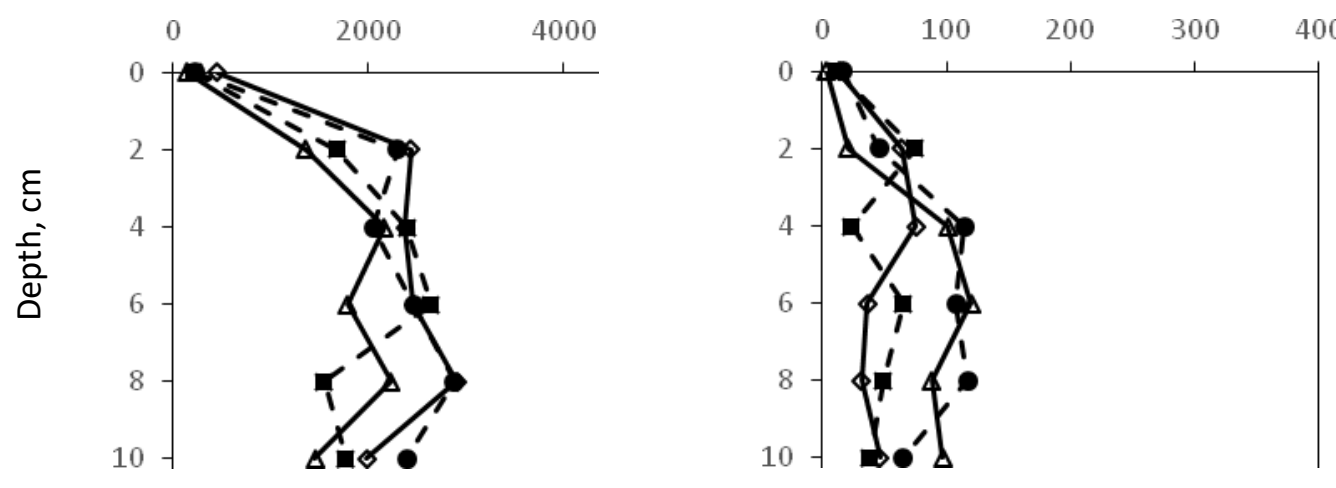

Site=BM
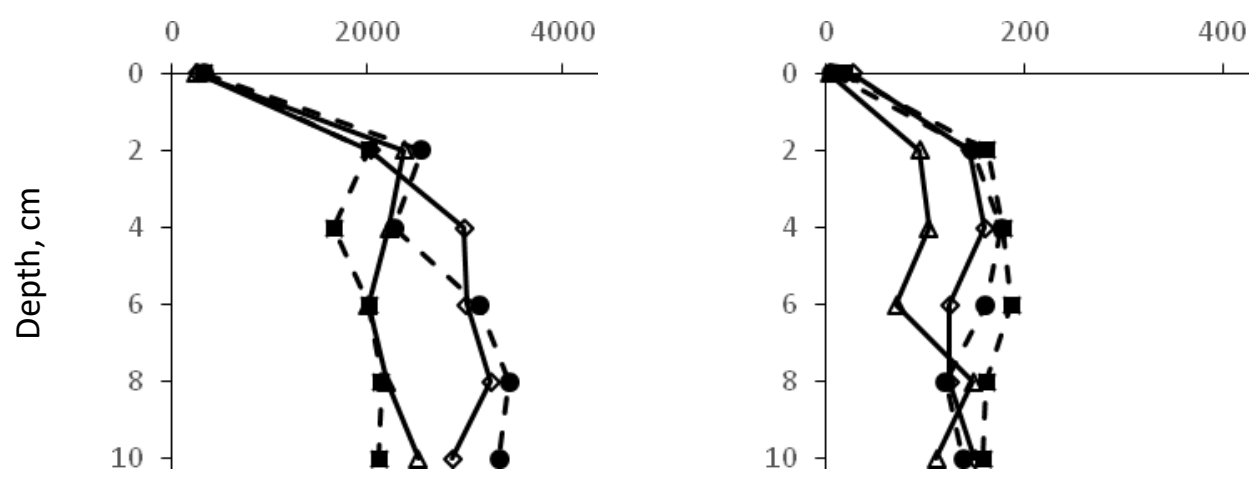

Site $=\mathrm{MA}$

$\multimap$ Summer $8 \mathrm{~h} \longrightarrow$ Winter $8 \mathrm{~h} \quad-$-Summer $48 \mathrm{~h} \quad-\bullet-$ Winter $48 \mathrm{~h}$

Figure 8.TN and TP in the pore water in the pore water after 8 and $48 \mathrm{~h}$ of incubation for spring and winter

\section{Nutrient flux}

DO and nutrient flux at sediment-water interface varied widely from release to uptake within $4 \mathrm{~h}$ and two days of incubation (Fig. 9). Oxygen and nutrient fluxes after the first $4 \mathrm{~h}$ of incubation were almost ten times higher than after the total $48 \mathrm{~h}$ of incubation. Oxygen flux varies over similar ranges in summer and winter, from -2.54 to $-2.09 \mathrm{mg} \mathrm{m}^{-2} \mathrm{D}^{-1}$ and from -2.1888 to $-1.8504 \mathrm{mg} \mathrm{m}^{-2} \mathrm{D}^{-1}$ after the first $4 \mathrm{~h}$ incubation. Significant differences $(p<0.05)$ were found between seasons at site MA in the first $4 \mathrm{~h}$ 
of incubation, where higher oxygen fluxes were found in summer. The difference determined during the two seasons suggests that the higher oxygen consumption coincided with higher macroagal decomposition, similar results were observed by Warnken et al. (2003). Nitrite fluxes were relatively low, in the range of 0.038 to 1.34 umol m $\mathrm{m}^{-2} \mathrm{D}^{-1}$ in summer and in the range of -0.1263 to 0.9210 umol m $\mathrm{m}^{-2} \mathrm{D}^{-1}$ in winter after the $4 \mathrm{~h}$ of incubation. Significant differences between seasons and among sites were observed. Nitrite uptake by the sediment after the first $4 \mathrm{~h}$ of incubation was demonstrated at site AR in winter. The maximum ammonium fluxes were recorded at site MA in winter after the first $4 \mathrm{~h}$ of incubation and at site BM in summer after the 48 $\mathrm{h}$ of incubation. Ammonium uptake by sediment was observed at site AR in both seasons after the $4 \mathrm{~h}$ of incubation. Phosphate exchange was generally very low, except for the high flux at site AR.
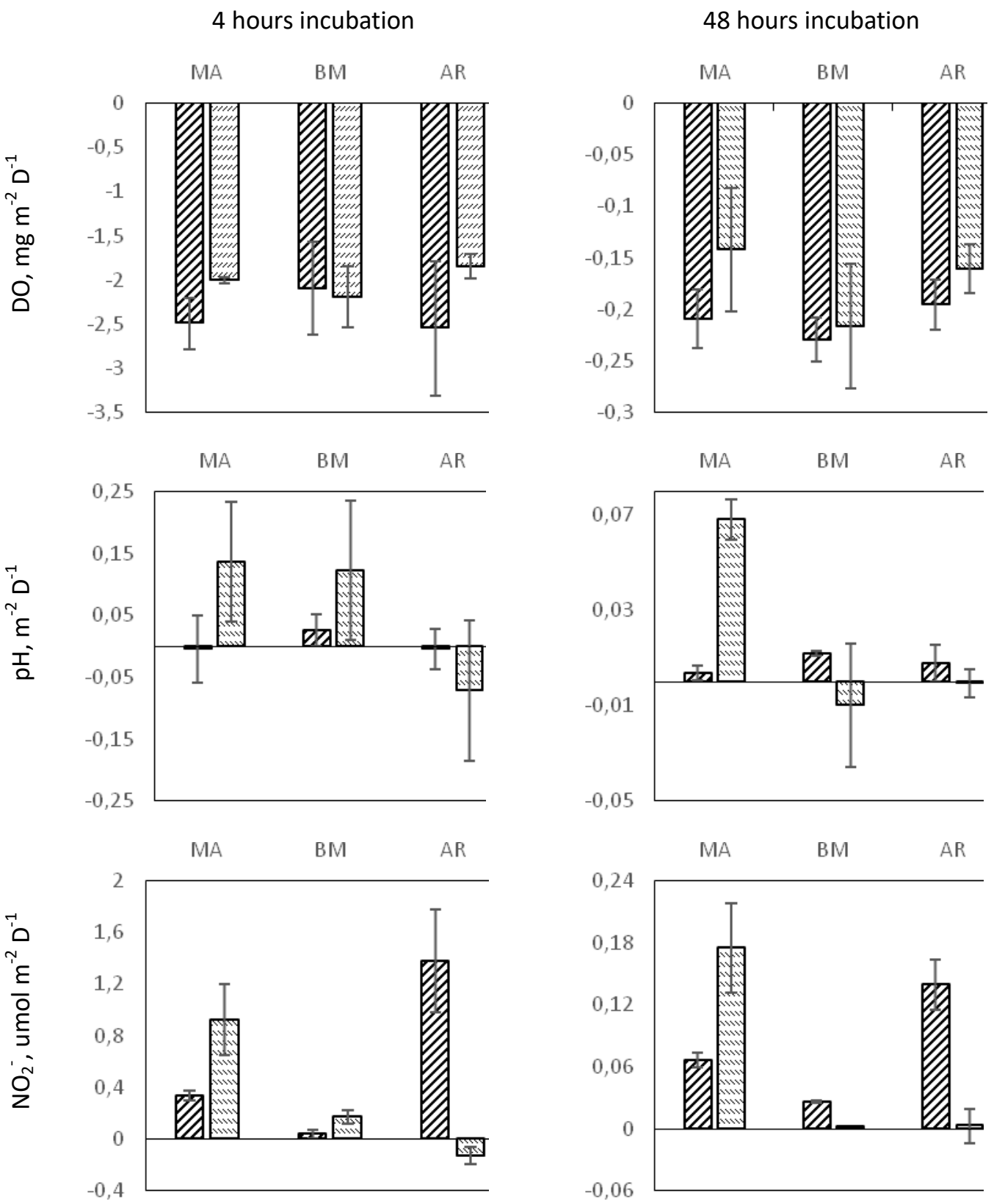


$$
-174 \text { - }
$$
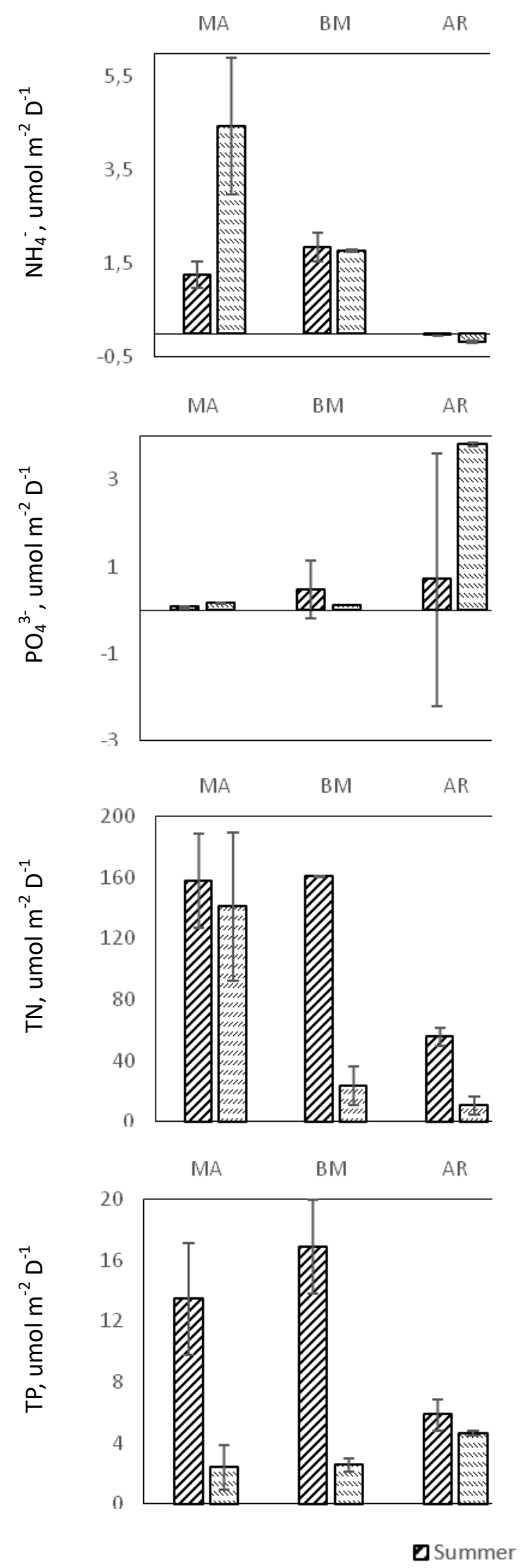
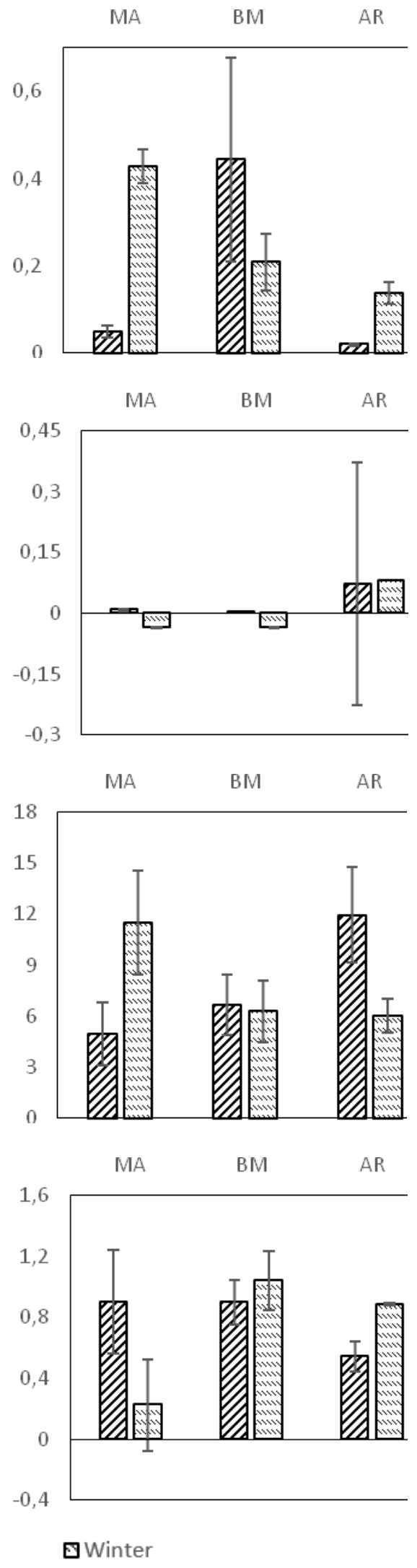

Figure 9. Oxygen, $p H$ and nutrient flux after $4 h$ and $48 h$ of incubation in summer and winter 
Average fluxes were in the range -0.1743 to 4.4478 umol $\mathrm{m}^{-2} \mathrm{D}^{-1}$. TN and TP were generally released from the sediment to the overlying water. A significant difference was observed between seasons after the $4 \mathrm{~h}$ of incubation, except at site MA. After $48 \mathrm{~h}$ of incubation, the highest TN and TP fluxes were recorded at site AR in summer, at site MA in winter, at site MA in summer and at site BM in winter.

\section{Discussion}

Benthos activities such as microorganism (Hines et al., 1982), shellfish (Castel, 1984; Chen et al., 2016b; 2005; Zhang et al., 2011; Zheng 2011), crabs (Zheng, 2011), and worms (Chen et al., 2016a) elicited rapid changes to nutrient exchange at sediment-water interface. These burrowing organisms bioturbate the sediment effectively flushing the nutrient and oxygen-rich water to considerable depth (Chen et al., 2016a; Miller, 1984; Rakotomalala et al., 2015). Spatial distribution of marine organisms in Zhelin Bay marine ranching area could be crucial to nutrient flux. Shu et al. (2015) reported that the $k$-dominance curve of macro-benthic abundance in Zhelin bay which showed that the seasonal trend in species diversity was winter $>$ spring $\approx$ autumn > summer. Otherwise, survey results showed that microbenthic in site BM was more than 2.0 times of site AR and 1.5 times of site MA (Chen et al., 2015), and highest molluscs density in site BM would be 200 ind. $\mathrm{m}^{-2}$ (Qin et al., 2016).

The pore water phosphate ${ }^{-}$concentration showed a gradual increase with depth, and ammonium concentrations varied from 2.428 to $55.68 \mathrm{umol} \mathrm{L}^{-1}$ and from 1.996 to 54.03 umol L$^{-1}$ in sites BM and MA respectively at both sites BM and MA for both seasons. Nitrite concentration showed a similar trend to ammonium. A similar trend was generally observed for nitrite concentration and phosphorus concentration (Denis and Grenz, 2003) and ammonia concentration (Sakamaki et al., 2006). Conversely, our results did not correspond with calculated in Bohai Bay coastal zone by $\mathrm{Mu}$ et al. (2016) who reported nitrite and DIN decreased with sediment depth.

Otherwise, decomposing organisms affected biogeochemical conditions of sediment (Chelsky et al., 2016; Wang et al., 2016). At site MA, higher nitrite, ammonia and phosphate fluxes were found in the winter, which was the same as the large scale macroalagae culture in this season. The high bloom of macroalgae would eventually become senescent and die. Decomposition of macroalgae stimulated sediment oxygen demand and an efflux of nitrogen and phosphorus (Wang et al., 2016). Welsh (2003) and Chelsky et al. (2016) study results showed that the physical barrier created by organism decomposition, reduces the transport of oxygen into the deeper sediment, however, our study did not show a similar trend. Benthic organisms, especially deposit feeders, will be present in this area and will be responsible for sediment reworking (Miller, 1984). This may explain the reason we found a similar trend in the MA and BM sites.

Moreover, hydrodynamics is an important factor that will influence sedimentsurface water flux; a range of models has been used characteristics (Arndt et al., 2009; Bianchi et al., 2004; D'Itri, 1985; Gardner and Kjerfve, 2006; $\mathrm{Hu}$ and Li, 2009; Proctor et al., 2003). The phosphate flux at site AR in this experiment was higher than at the other sites. Also, if artificial reef deployment is to improve and increase fishery resources in the local area, then, it will affect the sediment-surface flux. In the early survey of Zhelin Bay ranching, the results showed higher fishery resources at site AR (Chen et al., 2015). Raoux et al. (2017) and Wu et al. (2016) also obtained higher 


$$
-176-
$$

fishery resources in artificial reef area. These biological and physical changes are the main reasons which influence nutrient fluxes.

\section{Conclusion}

This preliminary study of different ecological functional zones used in marine ranching is useful for explaining the ecological function of different zones. Macroalgae decomposition showed the effect of overlying water nutrient concentration and nutrient fluxes which led to highest $\mathrm{pH}$ variation and highest nitrite, ammonia and total nitrogen fluxes in winter. As a presumed function of bioturbation in site BM, nutrient concentration in surface water increased quickly, while pore water nutrient kept in a stable level. Furthermore, artificial reef deployment changed the physical environment of sea bed and created upwelling at that area, which increased the flux of total phosphate. Our research results provide a basis for more specific studies towards the impacts on biological geochemistry of marine ranching construction. Further investigation should consider the physical feature of the sediment and induce biological species to study the bioturbation and physical changes of ecosystems.

Acknowledgements. The authors would like to thank Dr. James Locascio, Mote Marine Laboratory in America, for comments on the manuscript. This work was supported by National Natural Science Foundation of China (Grand No. 41206119), National Key Technology Research and Development program of the Ministry of Science and Technology of China (Grand No. 2012BAD18B02), Central Public-interest Scientific Institution Basal Research Fund, South China Sea Fisheries Research Institute, CAFS (2017YD04) and China Scholarship Council. In addition, I would like to thank the anonymous reviewers who have helped to improve the paper.

\section{REFERENCES}

[1] Arndt, S., Regnier, P., Vanderborght, J.-P. (2009): Seasonally-resolved nutrient export fluxes and filtering capacities in a macrotidal estuary. - Journal of Marine Systems 78(1): 42-58.

[2] Bell, J. D., Leber, K. M., Blankenship, H. L., Loneragan, N. R., Masuda, R. (2008): A new era for restocking, stock enhancement and sea ranching of coastal fisheries resources. - Reviews in Fisheries Science 16(1-3): 1-9.

[3] Bianchi, F., Ravagnan, E., Acri, F., Bernardi-Aubry, F., Boldrin, A., Camatti, E., Cassin, D., Turchetto, M. (2004): Variability and fluxes of hydrology, nutrients and particulate matter between the Venice Lagoon and the Adriatic Sea. Preliminary results (years 20012002). - Journal of Marine Systems 51(1-4): 49-64.

[4] Camp, E. V., Lorenzen, K., Ahrens, R. N. M., Barbieri, L., Leber, K. M. (2013): Potentials and limitations of stock enhancement in marine recreational fisheries systems: an integrative review of Florida's red drum enhancement. - Reviews in Fisheries Science 21(3/4): 388.

[5] Castel, J. (1984): Influence of bioturbation by the clam (Ruditapes philippinarum) on meiobenthic communities Japanese clam. - Comptes Rendus de l'Academie des Sciences Serie 3 Sciences de la Vie (France) 299(19): 761-764.

[6] Chelsky, A., Pitt, K. A., Ferguson, A. J. P., Bennett, W. W., Teasdale, P. R., Welsh, D. T. (2016): Decomposition of jellyfish carrion in situ: Short-term impacts on infauna, benthic nutrient fluxes and sediment redox conditions. - Science of The Total Environment 2016(566-567): 929-937. 
[7] Chen, M., Ding, S., Liu, L., Wang, Y., Xing, X., Wang, D., Gong, M., Zhang, C. (2016a): Fine-scale bioturbation effects of tubificid worm (Limnodrilus hoffmeisteri) on the lability of phosphorus in sediments. - Environmental Pollution 219: 604-611.

[8] Chen, M., Ding, S., Liu, L., Xu, D., Gong, M., Tang, H., Zhang, C. (2016b): Kinetics of phosphorus release from sediments and its relationship with iron speciation influenced by the mussel (Corbicula fluminea) bioturbation. - Science of The Total Environment 542(Part A): 833-840.

[9] Chen, P., Qin, C., Yu, J., Yuan, H., Shu, L., Li, X., Zhou, Y. (2015): Survey report of fishery resources in Zhelin bay in 2012, p. 456. - South China Sea Fisheries Research Intitute, Chinese Academy of Fishery Sciences.

[10] Chen, Z., Liu, J., Xu, S., Wang, D., Zheng, X. (2005): Impact of macrofaunal activities on the DIN exchange at the sediment-water interface along the tidal flat of Yangtze River estuary. - Environmental Science 26(6): 43-50.

[11] D'Itri, F. M. (1985): Artificial Reefs: Marine and Freshwater Applications. - Lewis Publishers, Chelsea, MI.

[12] Denis, L., Grenz, C. (2003): Spatial variability in oxygen and nutrient fluxes at the sediment-water interface on the continental shelf in the Gulf of Lions (NW Mediterranean). - Oceanologica Acta 26(4): 373-389.

[13] Gaertner-Mazouni, N., Lacoste, E., Bodoy, A., Peacock, L., Rodier, M., Langlade, M.-J., Orempuller, J., Charpy, L. (2012): Nutrient fluxes between water column and sediments: Potential influence of the pearl oyster culture. - Marine Pollution Bulletin 65(10-12): 500-505.

[14] Gardner, L. R., Kjerfve, B. (2006): Tidal fluxes of nutrients and suspended sediments at the North Inlet-Winyah Bay National Estuarine Research Reserve. - Estuarine, Coastal and Shelf Science 70(4): 682-692.

[15] Grasshoff, K., Kremling, K., Ehrhardt, M. (2009): Methods of Seawater Analysis. Wiley - VCH, Weinheim, New York, Chichester, Brisbane, Singapore, Toronto.

[16] Hair, C., Mills, D. J., McIntyre, R., Southgate, P. C. (2016): Optimising methods for community-based sea cucumber ranching: Experimental releases of cultured juvenile Holothuria scabra into seagrass meadows in Papua New Guinea. - Aquaculture Reports 3: 198-208.

[17] Han, Q., Keesing, J. K., Liu, D. (2016): A review of sea cucumber aquaculture, ranching, and stock enhancement in China. - Reviews in Fisheries Science \& Aquaculture 24(4): 326-341.

[18] Hines, M. E., Orem, W. H., Lyons, W. B., Jones, G. E. (1982): Microbial activity and bioturbation-induced oscillations in pore water chemistry of estuarine sediments in spring. - Nature 299(5882): 433.

[19] Hu, J., Li, S. (2009): Modeling the mass fluxes and transformations of nutrients in the Pearl River Delta, China. - Journal of Marine Systems 78(1): 146-167.

[20] Kim, D., Woo, J., Yoon, H.-S., Na, W.-B. (2016): Efficiency, tranquillity and stability indices to evaluate performance in the artificial reef wake region. - Ocean Engineering 122: 253-261.

[21] Layman, C. A., Allgeier, J. E., Montaña, C. G. (2016): Mechanistic evidence of enhanced production on artificial reefs: A case study in a Bahamian seagrass ecosystem. Ecological Engineering 95: 574-579.

[22] Leber, K. M. et al. (ed.) (2004): Stock Enhancement and Sea Ranching: Developments, Pitfalls and Opportunities [electronic resource], $2^{\text {nd }}$ ed. - Blackwell, Oxford.

[23] Lorenzen, K. A. I., Leber, K. M., Blankenship, H. L. (2010): Responsible approach to marine stock enhancement: an update. - Reviews in Fisheries Science 18(2): 189-210.

[24] Miller, M. F. (1984): Bioturbation of intertidal quartz-rich sands: a modern example and its sedimentologic and paleoecologic implications. - Journal of Geology 92: 201-216. 


$$
-178-
$$

[25] Mu, D., Yuan, D., Feng, H., Xing, F., Teo, F. Y., Li, S. (2016): Nutrient fluxes across sediment-water interface in Bohai Bay Coastal Zone, China. - Marine Pollution Bulletin 114(2): 705-714.

[26] Proctor, R., Holt, J. T., Allen, J. I., Blackford, J. (2003): Nutrient fluxes and budgets for the North West European Shelf from a three-dimensional model. - Science of the Total Environment 314-316(0): 769-785.

[27] Qin, C., Chen, P., Yuan, H., Li, X., Li, C., Li, G., Feng, X. (2016): Comprehensive proliferation method of belzungia in tropical and subtropical marine ranching. - State Intellectual Property Office of the People's Republic of China.

[28] Qin, C., Yuan, H., Li, X., Chen, P., Zhang, A. (2012): Determining system for flux of bottom mud nutritive salt under condition of simulating natural environment. - South China Sea Fisheries Research Institute, CAFS China.

[29] Rakotomalala, C., Grangeré, K., Ubertini, M., Forêt, M., Orvain, F. (2015): Modelling the effect of Cerastoderma edule bioturbation on microphytobenthos resuspension towards the planktonic food web of estuarine ecosystem. - Ecological Modelling 316: 155-167.

[30] Raoux, A., Tecchio, S., Pezy, J.-P., Lassalle, G., Degraer, S., Wilhelmsson, D., Cachera, M., Ernande, B., Le Guen, C., Haraldsson, M., Grangeré, K., Le Loc'h, F., Dauvin, J.-C., Niquil, N. (2017): Benthic and fish aggregation inside an offshore wind farm: Which effects on the trophic web functioning? - Ecological Indicators 72: 33-46.

[31] Rasheed, M., Badran, M. I., Huettel, M. (2003): Influence of sediment permeability and mineral composition on organic matter degradation in three sediments from the Gulf of Aqaba, Red Sea. - Estuarine, Coastal and Shelf Science 57(1-2): 369-384.

[32] Sakamaki, T., Nishimura, O., Sudo, R. (2006): Tidal time-scale variation in nutrient flux across the sediment-water interface of an estuarine tidal flat. - Estuarine, Coastal and Shelf Science 67(4): 653-663.

[33] Seaman, W. (2000): Artificial reef evaluation: with application to natural marine habitats. - CRC Press, Boca Raton, FA.

[34] Seeberg-Elverfeldt, J., Schlüter, M., Feseker, T., Martin Kölling (2005): Rhizon sampling of porewaters near the sediment-water interface of aquatic systems. - Limnology and Oceanography: Methods 3: 361-371.

[35] Shu, L., Chen, P., Li, X., Qin, C., Yu, J., Zhou, Y., Yuan, H. (2015): Macrobenthic species diversity in the waters surrounding Zhelin Bay. - Journal of Fishery Sciences of China 22(3): 501-516.

[36] Taylor, M. D., Chick, R. C., Lorenzen, K., Agnalt, A.-L., Leber, K. M., Blankenship, H. L., Haegen, G. V., Loneragan, N. R. (2016): Fisheries enhancement and restoration in a changing world. - Fisheries Research 186: 407-412.

[37] Wang, Y., Li, Z., Qin, C., Chen, P., Yuan, H., Zhou, W. (2016): Effect of Gracilaria confervoides after falling off on overlying water of seaweed field in different seasons. South China Fisheries Science 12(2): 13-20.

[38] Warnken, K. W., Gill, G. A., Dellapenna, T. M., Lehman, R. D., Harper, D. E., Allison, M. A. (2003): The effects of shrimp trawling on sediment oxygen consumption and the fluxes of trace metals and nutrients from estuarine sediments. - Estuarine, Coastal and Shelf Science 57(1-2): 25-42.

[39] Welsh, D. T. (2003): It's a dirty job but someone has to do it: the role of marine benthic macrofauna in organic matter turnover and nutrient recycling to the water column. Chem Ecol 19: 321-342.

[40] Wu, Z., Zhang, X., Lozano-Montes, H. M., Loneragan, N. R. (2016): Trophic flows, kelp culture and fisheries in the marine ecosystem of an artificial reef zone in the Yellow Sea. - Estuarine, Coastal and Shelf Science 182(Part A): 86-97.

[41] Zhang, L., Shang, J., Wang, Z., Shen, Q., Fan, C. (2011): Bioturbation effects of Corbicula fluminea on sdeiment-water interface progresses and its metabolic rate in water. - China Environmental Science 31(6): 1001-1006. 
[42] Zhang, L., Wang, L., Yin, K., Lü, Y., Zhang, D., Yang, Y., Huang, X. (2013): Pore water nutrient characteristics and the fluxes across the sediment in the Pearl River estuary and adjacent waters, China. - Estuarine, Coastal and Shelf Science 133(0): 182-192.

[43] Zheng, K. (2011): Benthi Nutrient Fluxes at Typical Areas in Chinese Coast, with Emphasis on Bioturbation. - Ocean University of China, Qingdao. 